\title{
Sinema Filmlerinde Estetik Haz, Bellek Ve Özneleştirme İlişkisi: “Brand New Testament" Filminin Ontolojik Analizi
}

\author{
Selçuk ULUTAŞ*
}

\section{Özet}

Sanat, insanlık tarihinin mücadele alanlarndan birisidir. İmgesel alanda devam eden bu mücadeleye 19. yüzyılın sonlarından itibaren sinemanın da dâhil olduğunu biliyoruz. Estetik bir objenin, estetik bir süjenin bedeni üzerindeki etkisini ise bahsedilen imgesel mücadele alanında "estetik haz" kavramı ile tanımlamaktayız. Estetik haz kavramının anlaşılır olması ve üzerinde felsefi bir tartışmanın yapılabilmesi ise ontolojik açıdan estetik objenin bir bilgi nesnesi olarak kabul edilmesi ile ilgilidir. Bu kabul sonrasında estetik objenin, estetik süje üzerinde yaratacağı tasarlanmış bir etkiden söz etmeye başlayabiliriz. Bu çalışmada estetik hazzın sanatçı tarafindan tasarlanmış düşüncelerle meydana getirilmek istenen bir duygulam olduğu ifade edilmektedir. Estetik haz kavramı, genel haz kavramının tanımlarını bir hayli aşarak toplumsal alanda özneler üzerinde yaratılan çok boyutlu bir etkiyi anlatmaktadır. Bu bağlamda çalışmanın amacı estetik hazzın varoluşunun, bellek ve özneleştirme kavramlarn ile ilgisini ortaya koymaktır. Çalışmanın son kısmında ise "Brand New Testament" isimli film, estetik felsefesi ve estetik haz kapsamında değerlendirilmiştir. Değerlendirmede kullanılan yöntem estetik objelerin varoluşlarmın anlaşılması için tercih edilen ontolojik analizdir. Bu yöntemle filmin yönetmeninin oluşturduğu kasıtl imgeler üzerinden yani ön ontolojik tabaka vasıtasıyla tasarımdaki bellek ve özneleştirici unsurlar ortaya çıkarılmak istenmektedir.

Anahtar Kelimeler: Estetik, Sinema, Haz, Bellek, Özne, Arzu, Ontoloji.

ORCID ID : https:/ / orcid.org/ 0000-0003-4804-0565

E-mail : selcukulutas@nevsehir.edu.tr

DOI: $10.31122 /$ sinefilozofi.631589

Geliş Tarihi - Recieved: 10.10.2019

Kabul Tarihi - Accepted: 27.03.2020 


\title{
The Relationships Between Aesthetics Pleasure, Memory and Subjectivation in Cinema Films: The Ontological Analysis of the Film \\ "Brand New Testament"
}

\author{
Selçuk ULUTAŞ*
}

\begin{abstract}
Art has been one of the arenas of the human history. We know that cinema was included in this struggle taking place in the imaginative field after the end of nineteenth century. We define the effect of an aesthetic object on the body of an aesthetical subject with the concept of aesthetical pleasure in the aforementioned imaginative field of struggle. Making the aesthetical pleasure understandable and conducting a philosophical discussion on it is related to accepting and aesthetical object as an object of information in terms of ontology. After accepting this, we can start to mention about a designed effect of the aesthetical object on an aesthetical subject. In this study, it is stated that aesthetical pleasure is an affectivity which was formed with the thoughts designed by the artist. The concept of aesthetical pleasure extremely exceeds the general definition of pleasure and describes a multi-dimensional effects created on subjects in social field. Within this context, the objective of the study is to reveal the relationships between the existence of the aesthetical pleasure and the concepts of memory and subjectivation. In the final chapter of the study, the film "Brand New Testament" was analyzed in terms of philosophy of aesthetics and aesthetical pleasure. The method employed in the evaluation is the ontological analysis which was preferred to understand the existence of aesthetical objects. Through this method, it is desired to reveal the memory and subjectivating elements in designs through the intentional images created by the director of the film, namely, through pre-ontological layer.
\end{abstract}

Keywords: Aesthetics, Cinema, Pleasure, Memory, Subject, Desire, Ontology

ORCID ID : https:/ / orcid.org/ 0000-0003-4804-0565

E-mail : selcukulutas@nevsehir.edu.tr

DOI: $10.31122 /$ sinefilozofi.631589

Geliș Tarihi - Recieved: 10.10.2019

Kabul Tarihi - Accepted: 27.03.2020 


\section{Giriş}

İnsanlık tarihinde sanatın toplumsal açıdan oldukça özel bir yeri bulunmaktadır. Sinemanın icadı sonrasında sanatın etkisinin kitlesel boyuta ulaştığı bilinir. Estetik felsefesi kapsaminda incelenmesi gereken bu etkinin boyutlarından birisi de estetik öznelerin sinema filmleri karşısında aldıkları estetik haz ile ilgilidir. Haz kelimesinin sınırlarını bir hayli aşan ve insan varoluşu için farklı bir deneyim alanından söz etme olanağı sağlayan estetik haz, bellek kavramı ve özne felsefesi ile de yakından ilgilidir.

Sinema filmleri, sanatın imgesel alanında özneler üzerinde kimi zaman bir tür direniş, kimi zamansa varolanı koruma şeklinde etkiler yaratarak estetik bir mücadele vermektedir. İmgesel alanda bahsedilen etkilerin estetik boyutunun anlaşılması adına literatürde sinema filmlerini birer estetik objektivasyon ${ }^{1}$ ve bilgi nesnesi olarak görme ĕgilimi söz konusudur. Sanat ontolojisi alanıyla doğrudan ilgili olan bu bakış açısı ile çalışmada sinema filmlerinin estetik özneler üzerindeki etkisinin estetik haz bağlamında ortaya konulması amaçlanmaktadır. Bu amaç çerçevesinde sinema filmlerinin yaratacağı estetik hazzın, filmin tasarımının bir parçası olduğu ifade edilmekte ve tasarım boyutunda estetik hazzın varoluşuna odaklanılmaktadır.

Estetik haz, sanat eserleri ile estetik özneninulaştığı tasarlanmış duyguları² anlatmaktadır. Ancak bu tanım tasarlanmış duyguların her seferinde istisnasız tüm öznelerde aynı şekilde oluşacağı anlamına gelmez. Tasarlanan ve estetik öznede oluşturulmaya çalışılan duygular ise doğrudan filmin yaratmaya çalıştığı kasıtlı düşünceler ${ }^{3}$ sayesinde ortaya çıkar. Bu çalışmanın temel söylemi; tasarlanmış düşünce ve duygular sayesinde plastik sanatlardaki diğer sanat eserleri gibi sinema filmlerinin de düşünce ve duygu bağlaminda bir bellek üretme misyonunu taşıdıklarıdır. Üretilen bu bellek ise literatürde kültürel bellek alanına dâhil edilmiştir. Kültürel bellek genel anlamda dışsal bir bellek olarak öznelerin kendi deneyimlemedikleri fenomenler ile ilgili bir çeşit özneleştirme pratiği olarak okunabilir. Tüm bunlarla birlikte sanat eserlerinin özneleştirici etkisi ve estetik haz arasındaki bağlantı da çalışmada incelenmektedir.

Çalışmanın son kısmında ise Brand New Testament ${ }^{4}$ (Yeni Ahit, Jaco Van Dormael, 2015) isimli film estetik haz bağlamında değerlendirilmiştir. Böyle bir değerlendirmenin gerçekleştirilmesi için tercih edilen yöntem ise ontolojik analizdir. Bu analiz ile çalışmada incelenen Brand New Testament isimli filmde tasarlanan ve nesneleştirilen düşünceler ve düşünce bağlamında ortaya çıkması istenen duygulamların tespit edilmesi amaçlanmaktadır. Böylelikle film ile estetik boyutta üretilen bellek ve özneleştirici unsurlar ortaya konulacaktır. İncelemeye alımlayıcı boyutu dâhil edilmemiştir.

\section{Yöntem}

Estetiğe dair modern bakış, aslında estetiğin sanatı değil, bilginin hassas alanını incelediği

\footnotetext{
${ }^{1}$ Kavramın orijinal yazılımı "objectivation" şeklindedir. Nesneleşme olarak çevrilen bu kavram sanat ontolojisi alanında sıradan bir nesneleşmeden ziyade oldukça kapsamlı bir anlama sahiptir. Bu sebeple nesneleşme kavramının kullanılması hatalı olacaktır. Kavramın tam Türkçe karşılığı bulunmadığı için çalışmada "objektivasyon" şeklinde kullanılmıştır.

${ }^{2}$ Çalışmada bu duygular "Duygulam" kavramı ile ifade edilmektedir. Duygulam kavramı Deleuze ve Guattari'nin Türkçeye "Felsefe nedir?" şeklinde çevrilen kitaplarından ödünç alınmıştır.

${ }^{3}$ Duygu oluşumu ile ilgili felsefe ve psikoloji alanındaki çalışmalara göre bazı duygular belli zamanlarda biliş dışı ve düşünceden bağımsız olarak da oluşabilmektedir. Bu durum tüm duyguların düşünce ile bağlantılı olmadığını ortaya koyar. Fakat insan yaşamını etkileyen pek çok duygunun düşünce boyutunda, inanç ve yargılarla bağlantılı olduğu bilinmektedir. Spinoza başta olmak üzere felsefe alanında pek çok düşünür bu durumu ortaya koyarken psikoloji alanında da son yıllarda yapılan çalışmalar duygu ve düşünce arasındaki güçlü ilişkiyi göstermektedir. Diğer taraftan estetik haz olarak tanımlanan tasarlanmış duyguların ise düşünceden bağımsız oluşması mümkün değildir (Solomon, 2004; Neu, 2000, Spinoza, 2011).

${ }^{4} 2015$ yılında gösterime giren ve yönetmen koltuğunda Jaco Van Dormael'i gördüğümüz "Brand New Testament" isimli film, Fransa ve Lüksemburg ortak yapımıdır.
} 
görüşüne geri dönmüştür ${ }^{5}$. Estetik bu sebeple sanata veya sanatın analizine ait bir alan değil, sanatın unsurlarını düşünce unsurları olarak değerlendirmenin bir yolu olarak görülmektedir. $\mathrm{Bu}$ bağlamda ontolojik analizinin estetik alanındaki rolü ancak, estetik unsurlar düşünce unsurları olarak kabul edildiğinde ortaya çıkmaktadır. Modern ontolojide nesneler fikirden başka bir şey değildir. Bu sebeple bazı fikirlerin imgelere sahip olduğu da söylenebilir. Bu felsefi düşünüş bizi görüntüleri akla bağlı olan şeyler olarak değerlendirmeye teşvik eder. Husserl'in idealist görüşü, her şeyin akla bağlı olduğunu belirtir. Bu durumda, sadece kurgusal nesnelerle uğraştığımızı ve böylece, kurgusal bir nesnenin imajına sahip olduğumuzu veya görüntülerin kendilerinin kurgusal nesneler olduğunu ifade edebiliriz (Nita, 2014).

Sanat eserlerinin bir nesne olarak, fiziki dünyada yer alan doğal nesnelerden farklı bir varoluşa sahip olduğu kabul edilmektedir. Bu varoluş Hartmann tarafından objektivasyon kavramı çerçevesinde açıklanmıştır. Kavram özetle sanat eserinin tinsel ve maddesel iki tabakadan oluştuğunu ve bu tabakaların meydana getirdiği bütünün bir bilgi nesnesi olduğunu ortaya koymaktadır. Fakat bu bilgi nesnesi tasarlanmış bir nesnedir ve nesnelerin içeriğinin (tinsel tabaka) bilgisine apriori olarak ulaşılabilir. Doğada kendinde varlık olarak tanımlanan nesneler için içerik aposterioridir ve öznenin deneyimlerine ve yorumlarına bağlıdır. Bu durum sanat eserinin bilgisinin diğer nesnelere kıyasla verili olduğunu bize gösterir. Böylelikle ile sanat eserinin varoluşu estetik öznenin yorumlarından bağımsızdır. (Tunalı,1996, Hartmann, 2010, Hartmann, 2014, Cicovacki, 2015).

Sanatın sunduğu bilgiye alımlayıcının ulaşabilmesi ise sanat eserinin nesnesinin duyumsanmasından geçmektedir. Duyumsanan şey plastik sanatlarda görüntüdür. Görüntü sanat eserinin bir parçasıdır ve düşüncenin estetik bir öğesidir. Eğer görüntüler düşüncenin öğeleriyse vekendi iç sembolleri için bilgiye ihtiyaç duyuyorlarsa, o zaman görüntüler toplumsal objektif varlıklardır. Görüntüler zamana bağlı anlamlar üretebilir, mekândan, kültürel veya sosyal çevreden bağımsız olarak farklı kuvvetler üretebilir. Bunun nedeni bir sanat eserinin varoluşunun estetik öznelerle buluşmasından itibaren iki tür görüntü içermesidir. Bunlardan ilki kasıtlı imge olarak tanımlanır ve sanat eserinin verili fikrinin somutlaştırılmasıdır. Diğeri ise aşkın görüntüdür ve görüntünün alımlayıcı tarafından çok sayıda yorum yapma ve sayısız anlamlar oluşturma imkânı ile ilgilidir. Aşkın görüntü ile ilgili sayısız yorum olanağı onu tam olarak tespit etme imkânını ortadan kaldırır (Nita, 2014).

Hartman'a göre estetik bir nesnenin ontolojik analizi estetik nesne veya estetik eylem ile ilgilidir. Estetik nesne, ontolojik yapısı veya estetik değer ${ }^{6}$ karakteri ile analiz edilebilir. Estetik eylem ise izleyicinin alıcı eylemi veya sanatçının yaratıcı eylemi olarak düşünülmüştür (akt. Cicovacki, 2015: 96). Bu çalışma izleyicinin estetik eylemini dışarda bırakarak sadece tasarıma yönelmektedir. Bir sinema filminin ontolojik analizi ise kasıtlı imgelerin, kendi bağlamında değerlendirilmesi ile ilgilidir. Bu analizin amacı sanatçının sunduğu verili bilgiye ulaşmaktır. Bu nedenle görüntünün aşkın hallerinden ziyade sanatçının tasarımına odaklanılmaktadır. Çalışmada Brand New Testament isimli filmin imgesel düzeyde bellek üretimi üzerine bir inceleme gerçekleştirilmektedir. Sanatçının tasarladığı düşünce ve duygulamların anlaşılması adına eserin ön-ontolojik ${ }^{7}$ seviyesi olarak kabul edilen nesnesi konunun sinırlılıkları çerçevesinde incelenecektir. Sinemada ön-ontolojik seviye ise görüntü ve ses unsurları ile yaratılan karakter, eylem ve olay, mekân ve zaman ile ilgili imgeler olarak karşımıza çıkar. Lakin aşağıda incelenen film hali hazırda özneleri etkileyen bir kültürel bellek ile mücadeleye girdiği için filmde gösterilmeyen ve eleştirilen bellek de filmin varoluşunun bir parçası olarak kabul edilmiştir.

Film incelemesinde kullanan yöntem ve çalışmanın genel literatür incelemesi ile sinema filmlerinin bellek üretme ve var olan belleklerle mücadelesinin ortaya konulması

\footnotetext{
${ }^{5}$ Bu düşünce estetik felsefesinin kurucusu kabul edilen Baumgarten tarafından ortaya konulmuştur.

${ }^{6}$ Estetik değer kavramı ile sanatsal nesnenin bir biçem olarak güzellik taşıması kast edilmektedir.

${ }^{7}$ Ontolojik bir inceleme Hartmann'a göre ön varlık alanı veya pre-ontolojik tabakada gerçekleştirilebilir (2014).
} 
amaçlanmaktadır. Böylelikle estetik haz ve bellek arasındaki ilişki ve özneleştirme süreçlerinin bellek ve hazla bağlantıları da çalışmada ele alınacaktır.

\section{Haz Kavramı ve Estetik Haz}

Haz kavramından asla korkmayan bir düşünür olarak Epikuros, büyük haz ve zevklerin tanımını; "İnsanın ekmek ve suyu aç ve susuzken bulması ne kadar hoş bir şeydir" şeklinde bir girizgâhla yapar. İnsan ihtiyaçları ve haz arasındaki bağlantıya değinen düşünür hazzın doğal ya da yapay ihtiyaçlarla ortaya çıkabileceğini vurgulamaktadır. Haz bir ödüldür. Bu ödül arzuların ve ihtiyacın gerçekleşmesi ile ortaya çıkar (Bonnard, 2014: 329). Haz kavramının açıklanması bağlamında arzu kavramı ve felsefede kullanımları da önem arz eder. Arzuyu, bir şeyi elde etme isteği olarak tanımlayan Timuçin (2004), arzunun gerçek ya da düşsel bir amaca yönelik, bilinçli veya bilinçsizce ortaya çıkabileceğini ve eğilimlerden beslendiğini belirtmektedir. Arzunun karşısına ise istem yani bir şeyi yapıp yapmama konusunda öznenin belirleyici konumu konulmaktadır. Bu sebeple arzu kavramı özgürlükle çelişen bir durumu işaret etmektedir.

İhtiyaç kuramından bahsettiği metinlerinde Hegel, arzu ve ihtiyaç kavramlarını kimi zaman aynı anlamda kullanmaktadır ve arzu, düşünüre göre ihtiyacın önemli bir boyutu olarak görülmektedir. Bu anlamda insan bir şeye ihtiyaç duymakta ve onu arzulamaktadır ${ }^{8}$. Arzu söz konusuysa hazzın belli bir süre ertelenmesi durumu ortaya çıkar. Bu ertelemede insan hazza ulaşmak için çalışmak durumundadır ki çalışma veya emek kavramları ertelenmiş haz anını tanımlar. Hazzın ertelenmesi durumu özgürlük sorununu ortaya çıkarır. Bu bağlamda emek, düşünürün etik yaşam bağlamında ihtiyaçla ilgili bildirdiği ilk üç aşamasında özgürlüğün anahtarı olarak yorumlanmışken, dördüncü aşamada bir takas ekonomisine geçildiği için kendi ürettiği artığı kullanamayan insan adına özgürlük ve dolayısıyla haz da daha karmaşık bir sorun haline gelmiştir (Fraser, 2008).

Bedensel hazlar ise Hegel'in perspektifinden ayrıca değerlendirildiğinde; ihtiyacın hissedilmesiyle ortaya çıkan gerilimin özneyi eyleme yönlendirdiği, ihtiyacın elde edilmesi ile bedensel hazzın ortaya çıtığ1 ve özgürlük anının kısa süreli yaşandığının, düşünür tarafından ifade edildiği görülmektedir. Nitekim ihtiyacın tekrar ortaya çıkması ile özgürlük anı sonlanacak ve bedensel haz ortadan kalkacaktır. Örneğin acıktığımızda açlığımızı ortadan kaldırmakla birlikte yaşanan haz yeniden açlık hissedildiğinde kaybolacaktır. Sonuç olarak bedensel hazlar literatürdeki farklı tanımlarına rağmen bedensel arzu veya ihtiyaçların giderilmesiyle ortaya çıkan ve tekrar arzu ya da ihtiyaç duyulması ile kaybolan geçici hazlar olarak tanımlanabilir.

Estetik haz olarak kavramsallaştırılan haz türünün varoluşu ise bedensel hazlardan bir hayli farklıdır. Bu farklılıklara dikkat çeken ve estetik hazdan söz eden düşünürlerden Kant için estetik haz, bir nesneyle tamamen kavramsal olmayan birleşmeden kaynaklanmaktadır. Kant'ın bu düşüncesi pek çok başka düşünür tarafından estetik deneyimin düşünce ve imgeden bağımsız yaşanamayacağı fikri paralelinde eleştirilmiştir. Buna göre genel olarak kabul gören en basit tanımıyla estetik haz, bir nesneden hem nesne karakteri (biçem) hem de içeriğinden alınan hazdır. Farklı bir şekilde ifade edilirse estetik haz içeriğin nesnedeki yansımaları ile ilgili olarak öznede ortaya çıkmaktadır. Bir sanat eserinin ahlaki, entelektüel, politik vb. içeriği, onun nesne olarak var edilişi yani nesnesinin biçemi ile estetik haz üretebilir. $\mathrm{Bu}$ durumda estetik hazın üretimi içeriğin biçemle organize edilmesi ile ilgilidir. Estetik haz sadece görünüşten ve biçemden haz almanın ötesinde çok daha derin bir durumu işaret eder (Cooper vd, 1999: 121-123).

Sanat eseri karşısında alınan haz ile fiziki dünyadaki duyumsal hazları karşılaştıran

\footnotetext{
${ }^{8}$ Modern ihtiyaç kuramcıları Hegel'in arzu ve ihtiyaç kavramları çelişkili bir şekilde kullanmasını eleştirirler. Örneğin bir şeker hastası şekeri arzular fakat onun ihtiyaç duyduğu şey şeker değil insülindir şeklinde bir açılamayla ihtiyaç ve arzuların kimi zaman aynı anlamda kullanılabilmesine rağmen bazı durumlarda ise farklı olduklarını göstermek isterler (Friser, 2008: 70).
} 
Hartmann, Croce ve Volket'in ortak görüşü öz bakımından estetik hazzın fiziki duygulardan farklı olduğu yönündedir. Düşünürlerin ortak kanaati ise estetik hazzın gerçek olmayan yani görüntü duyguları ile ilgili olduğu yönündedir. Croce bu görüntü duygularının sanat eserinin içeriği sayesinde oluştuğu vurgusunu yapar (akt. Tunalı, 1973: 52). Kagan (1993) ise insanların sanat eserlerinden aldıkları estetik hazzın fiziki dünyadaki nesnelerden alınan hazdan farklı olduğunu vurgulayan başka bir düşünürdür. Kagan için estetik hazzın iki boyutu söz konusudur. Bunlardan ilki izleyicinin sanat eserinin biçemi karşısındaki hayranlığ ile ilgilidir. Diğeri ise sanatçı tarafından nesneleştirilen içeriğin, alımlayıcının zihninde tekrar üretilmesi ve sanatçının ürettiği anlamlar dünyasına öznelerin girmeyi başarmasının verdiği hazdır. Bu iki boyutuyla estetik hazzın duyumsal hazlardan farklılaştı̆̆ını söyleyen Kagan, estetik hazzı bir sanat eserinin varoluşunun değerlendirilmesinden alınan haz olarak tanımlamaktadır.

Özel bir varoluşa sahip olan sanat eserleri için estetik haz, duyumsal hazlardan başka şekillerde de farklılaşmaktadır. Duyumsal hazlara sevinç türevi duygular eşlik ederken, bu hazların pozitif duygularla alakalı olduğu belirtilmelidir. Estetik haz ise hem sevinç hem de keder türevi duygular ile ilgilidir ve bu nedenle pozitif duyguların yanı sıra negatif duyguların da oluşması estetik haz kavramı çerçevesinde değerlendirilmektedir (Tunalı, 1996). Estetik hazzın duygularla olan bu farklı ilişkisi estetik kavramının güzel kavramı ile eş anlamlı kullanılmasını da engeller. Bu nedenle güzel dışında pek çok başka estetik kategoriden de söz etmek mümkün hale gelir. Ancak burada üzerinde durulması gereken nokta, negatif duyguları oluşturan unsurun sanat eserinin içeriği olduğudur. Bu nedenle çirkin, korkunç, trajik, komik gibi kategorilerde, eserlerin biçemlerinde güzellik ${ }^{9}$ nosyonu devre dışı kalmamaktadır. İçerik her ne olursa olsun biçem, güzellik yani estetik değer taşımak zorundadır.

Güzel dışında diğer estetik kategorilerin varlığı ve bunların ürettikleri negatif duyguların sanatla nasıl ortaya çıktığı hakkında düşünen isimlerden birisi de Nietzsche'dir. "Ç̧rkin ve uyumsuz olan, trajik mitosun içeriği, estetik bir hazzı nasıl doğurabilir?" sorusunu soran düşünür dünyanın ve varoluşun sadece estetik bir varlık ile haklı olarak gösterilebileceğine dikkat çeker. Bu sebeple Nietzsche'nin çirkin, uyumsuz ve trajik olanı bile sanatsal bir oyun (deneyim) olarak gördüğü ve bu oyunun yarattığı zevk sayesinde bizi ikna edebileceğini söylediği bilinir. Apollon ve Dionysos ayrımı ile sanatın varoluşunu anlatan düşünür, Apollon'u sanatın biçemi, Dionysos'u ise eserlerin yaratacağı her türlü duygu ile ilişkilendirmiştir. Çirkin, uyumsuz ve trajik olanın yaratacağı negatif duygular ve estetik haz bu sebeple Dionysos ile ilişkilidir ancak Dionysos bu etkiyi Apollon'un alanında yaratmak zorundadır. Düşünür, Dionysos'un etkisinin azalması durumunda Apollon'un tek başına sadece güzel nesneler sunabileceğini söyler ve her türlü olumsuz veya olumlu duygunun ve estetik hazzın bu iki tanrının birlikteliğinden ortaya çıktığını ifade eder (2005: 157).

Estetik haz sanatçı tarafından tasarlanmış duygudur. Bu duygu duygulam olarak tanımlanır ayrıca zorunlu ve genel geçerdir. Duygulam bu sebeple ontolojik olarak a priori bilgi ile üretilmiştir. Diğer bir ifade ile sanat eserinin içeriği duygulamı üretecektir ve bu içerik verilidir. Belirlenmiş bu verili içeriğin duygulamları üreteceği düşünüldügüünde estetik hazzın yani duygulamların sanatçı tarafından bilinçli bir şekilde tasarlandığını ifade edebiliriz. Böylelikle estetik hazzı yaşayan estetik özne, herhangi bir fenomen karşısında çeşitli duygulanımlar yaşayan ve bu duygulanımlarını sanat eseri vasıtasıyla nesneleştiren sanatçının bakış açısından o fenomeni estetik olarak alımlamakta ve sanatçının amaçladığı şekilde duygulanmaya diğer ifade ile duygulamlar yaşamaya başlamaktadır. Bu nedenle estetik haz sanatçının sezgisinin alımlayıcı tarafından keşfedilmesi ile ortaya çıkar (Deleuze ve Guattari, 2001; Hartmann, 2010; Gadamer,2009; Bozkurt, 2013).

Tasarlanmış bir duygulam olarak tanımladı̆̆ımız estetik haz, sanat eseri vasıtasıyla alımlayıcının yaşadığı deneyimi işaret etmektedir. Bu deneyim öznelerin gündelik

\footnotetext{
${ }^{9}$ Güzellik kavramı bir nesnenin biçimsel açıdan değerlendirilmesi ile ilgilidir ve söz konusu bir sanat eseri olunca güzellik ile estetik değer ifade edilmektedir. Güzel ise estetik felsefesi literatüründe bir estetik kategori olarak hem biçem hem de içerikle ilgilidir.
} 
hayatlarında deneyimlerinden farklı olarak özneye kuvvet uygulamayı amaçlayan bir başka öznenin üretimidir. Her sanat eseri estetik hazzın öznelerde oluşması koşuluyla virtüel bir deneyim olarak tanımlanabilir. Bu durum hem bellek kavramı hem de özneleşme kavramları ile yakından ilgilidir.

Estetik haz ile duyumsal haz arasında önemli bir diğer fark ise bellek alanında karşımıza çıkar. Duyumsal hazlar yukarıda da değinildiği üzere ihtiyacın yeniden ortaya çıkması ile ortadan kalkan haz türüdür. Bu nedenle kalıcı bir haz değildir. Özellikle tat alma, dokunma ve koku alma duyuları ile elde edilen duyumsal hazların kalıcı bir bellekte var olmadığı ifade edilebilir. Ancak estetik hazlar için durum farklıdır. Bir tür virtüel deneyim olan ve estetik alımlama sonrasında görsel veya işitsel duyulara dayanan haz, negatif veya pozitif duygulamlarla insan belleğinde fenomenlerin yorumlanması bağlamında kalıcı olabilmektedir (Tunal1, 1999; Bozkurt, 2013). Entelektüel, ahlaki, dini, politik vb. düzlemde tasarlanan estetik haz izleyende önce düşünce sonra duygulam boyutunda var olur. Bu bağlamda duygulamları öncüleyen düşüncelerin olması ve bu düşüncelerin duyguya evrilmesi süreci estetik hazzın bellekte bir tür deneyim olarak kalıcı olmasına neden olmaktadır. Duyumsal hazlarda ise yaşanan pozitif duyguların meydana gelmesinin temelinde düşünceler bulunmamaktadır. Yani bir yemekten zevk almak öncesinde veya sonrasında o yemekle ilgili olumlu düşüncelere sahip olmakla ilgili değildir ve tamamen maddeseldir.

İnsan belleği ve hatırlama eylemi ile duygular arasında ise güçlü bir ilişki söz konusudur. Bellek insana sürekli ihanet eden ve pek çok şeyi unutmamıza neden olan bir yapıdadır. Lakin gündelik hayatın içinde duygu yoğunluğunun arttığı olayları daha rahat hatırladığımızı ifade edebiliriz. Örneğin yaşanan üzücü bir olay ya da çok mutlu olduğumuz bir an gündelik hayatın içindeki diğer sıradan anlara kıyasla daha fazla hatırlanma potansiyelini taşır. Olan biteni tam hatırlayamasak bile geçmiş hislerin çoğu şimdi verilecek kararları da etkilemektedir. Bu bağlamda gerçek olmayan olaylarla bizlere çeşitli duygular yaşatmayı başaran sanat eserlerinde örneğin bir sinema filminde olayları tam hatırlamasak bile gerçek bir estetik deneyim yaşadığımız zaman bu deneyimin kalıcı olacağını, düşünce ve tutumları etkileyeceğini ifade edebiliriz. Başka şekilde söylenirse öznelerin estetik haz yaşadıkları eserler insan varoluşuna, duygu boyutunda bellekte kalma başarılarına göre dahil olmaktadırlar.

\section{Sanat ve Bellek ilişkisi}

İnsan varoluşunun en önemli unsurlarından birisi olan bellek gerek fenomenler ve zamanla gerekse duygulanım ve duygulamlar ile ilişkimizde özel bir yere sahiptir. Belleği çeşitli farklı şekillerde kategorize ederek açıklayabiliriz. Bellek türlerini sınıflandıran ve tanımlayan Assman'a göre belleği başlangıçta içsel ve dışsal olarak iki türde düşünmek mümkündür. İçsel bellek türleri, "Mimetik bellek, nesneler belleği ve iletişimsel bellek" olarak tanımlanır. Tasarlanan bir bellek olarak "Kültürel bellek" ise dişsal bir bellek olarak ifade edilmiştir. Kültürel bellek topluluklarda bireylere anlam aktarımını sağlamakta ve içsel bellek türleri ile bir bütünlük halinde olduğu vurgulanmaktadır. Toplumsal alanda devredilen, canlandırılan, canlı tutulmaya çalışılan her şey kültürel bellek ile ilgilidir (2001).

Belleğin içsel ve dışsal olarak konumlandırılması iki bellek türünün birbirlerinden bağımsız olarak düşünülmesi anlamına gelmez. Bu konu ile ilgili çeşitli tartışmalar arasında önemli görüşlerden birisi Schudson'a aittir. Toplumsal olandan bağımsız bir bellek türünün olmayacağı yönündeki açıklaması ile Schudson (2007: 181), öznelerin toplumsal alanda kanun, ahlak, din gibi standartlaştırılmış usuller ve kayıtlar ile bir dizi özneleştirici pratikle karşı karşıya olduklarını ifade eder. Bu özneleştirici pratiklerin arasında anıtlar, bayramlar, sanat eserleri ve andaçlar gibi kültürel bellek uygulamaları da vardır. Bu nedenle bir ağ şeklinde insanı saran toplumsal yaşam yüzünden bireysel belleğin kendine has bir yeri ve özellikleri olsa dahi toplumsal ve kültürel sınırlarının dışına çıkması zor görülmektedir. Bunun temel nedeni bireysel belleğin toplumsal bir yapı olan dilin sınırları içinde var olması ve toplumsaltarihsel süreçlerle iç içe olmasıdır. 
Huyssen kayıt edilen tüm temsil biçimlerinin bellek ile ilgisini ortaya koyar. Bir olay1 doğrudan fiziki dünyada deneyimlemekle sanat ile deneyimlemek arasında büyük bir fark olduğunu söyleyen yazar, sanat ile deneyimlenen ve estetik bir boyuta taşınan her şeyin bellekte canlı kaldığını belirtmektedir $(1999,13)$. Bu bağlamda insanın kendi deneyimlerini yorumlamasında elbette hem içsel hem de dışsal bütün bellek türlerinin etkisi olduğunu ancak sanat vasitasıyla yaşanan deneyimde tasarlanmış bir belleğin yani dişsal bir belleğin özneleri sardığı görülmektedir. Sanat eserleri birer deneyim alanı olarak sundukları dışsal bellekle öznelere eserin zamanı ne olursa olsun ontolojik olarak bilgi aktarmaktadır. Eserler bu anlamda geçmiş, şimdi veya gelecekle ilgili olabilir. Örneğin, İkinci Dünya Savaşının insanlık adına açtı̆̆1 yaraları anlatan "The Pianist" filmi veya Napolyon ordularına direnen Madridli İspanyolları gösteren, İspanyol ressam Goya'nın "The Third of May" isimli eseri geçmiş ile ilgili tasarlanmış bir belleği tüm zamanlara taşımaktadır. Nuri Bilge Ceylan'ın "Kış Uykusu" filmi günümüz Türkiye'sinin aydın profili ile ilgili diğer tarafta Andy Warhol'un pek çok eseri ise tüketim fenomeni ile ilgili güncel ve şimdiki zamanı gösteren kurgusal bir bellek sunmaktadır. Wells'in radyoda sunulan ve sinemaya da aktarılan "Dünyalar Savaşı"10 isimli edebi eseri ve bilimkurgu konusunda çalışan ressam, yönetmen ve diğer sanatçılar ise gelecek ile ilgili bir düşünsel perspektifi bellek unsuru olarak sunmaktadır. Bu dişsal bellek öznelerin fenomenleri değerlendirmelerinde önemli bir yere sahiptir. Tüm bunların yanı sıra fiziki dünyada var olmayan fenomenleri de tasarlamak, onlarla ilgili bir dışsal bellek üretmek ve çeşitli duygulamları yaratmak mümkündür. Sanat tarihinden bu konuyla ilgili binlerce örnek verilebilir. Mitolojik olaylar ve özellikle Ortaçağ Hıristiyan sanatındaki cehennem tasvirleri ise belki de bu duruma en iyi örneklerdir.

Sonuç olarak üretilen sanat eserlerini, kültürel bellek alanındaki bir mücadele olarak okumak ve bunu da iki temel tür olarak düşünmek mümkündür. Bu türlerden ilki bir kültürel bellek unsuru olarak resmi veya egemen söylemlerin tekrar edildiği eserleri, diğerini ise alternatif söylemlerin ve farklı bakış açılarının üretildiği eserleri kapsamaktadır. Her iki türde de üretilen sanat eserleri özneler üzerinde belli etkiler yaratmak için tasarlanmaktadır. Estetik hazzın bellek üzerinde kalıcı olarak yaratacağı bu etkinin bir çeşit özneleştirme pratiği olduğunu da ifade edebiliriz. Nitekim bu ifade sanat eserlerinin ve estetiğin ontolojik olarak bilgi alanı ile ilgili olduğunun kabul edilmesi fikri ile uyumdur.

\section{Özneleştirme ve Estetik Haz}

Estetik haz ile arzu ve ihtiyaç arasındaki ilişki duyumsal hazlardan farklıdır. Duyumsal hazlar bir ihtiyaç veya arzunun giderilmesi sonrasında öznenin elde ettiği ödül olarak yorumlanmaktadır. Bu ödül çoğunlukla doğal bir durumu işaret eder. Sanat eserleri ve sinema ile ilgili alımlayıcı öznenin ihtiyacı ise manevi bir ihtiyaç olarak ortaya çıkmaktadır ${ }^{11}$. İnsanın sanat tarafından sunulan virtüel deneyimle manevi varoluşunu genişletmeye olan ihtiyacı özel bir ihtiyaçtır. Bu durumu tinin beslenmesi olarak açıklayabileceğimiz gibi kimi öznelerin fenomenleri anlama çabası olarak da yorumlayabiliriz. Ancak sanata olan ihtiyacı, estetik hazza olan ihtiyaç olarak tanımlamak sorunlu gözükmektedir. Estetik haz bir sonuç olarak öznelerden bağımsızdır. Diğer taraftan çağlar boyunca sanat tarihinde karşımıza çıkan tüm eserlerini öznelerin sanata olan manevi ihtiyacının karşılanması için üretilen estetik nesneler olarak tanımlayamayız. Sanat tarihinin pek çok döneminde sanat eserleri ile onları duyumsayanlar arasındaki ilişki bir ihtiyaç ilişkisinden ziyade bir maruz kalma durumunu bize gösterir. Uygar toplumlarla birlikte iktidarların himayesine geçen sanat bu durumda halkların değil kendisine hükmeden egemen sınıfların veya alternatif söylemlerin var olma ihtiyaçlarını ve diğer arzularını dolaylı yoldan gidermek amaçlı olarak üretilmiştir. Bu durumda özneleşme kavramı ve estetik haz arasındaki ilgi ortaya çıkar. Uygarlık tarihindeki hemen tüm dönemlerde, sanat alımlayıcısının ihtiyacından veya arzusundan ziyade eserin üreticisinin (sanatçı veya eseri yaptıran kişi, iktidarlar vb.) arzusu ön plana çıkmaktadır.

\footnotetext{
${ }^{10}$ Orson Welles tarafından radyoda sunulmuş ve dinleyenlerde ciddi bir korkuya neden olmuştur.

${ }^{11}$ Sanat alıcısının meta boyutunda bir esere sahip olma arzusu bu konunun dışındadır.
} 
Çağlar boyunca insanları etkilemenin en önemli araçlarından birisi olan sanat bu bağlamda çeşitli bakış açıları ve fenomenlerle ilgili bilgiyi, üretilen düşünce ve duygulamlar vasıtasıyla sunmaktadır. Bu sunuş bir sanat eserleri ile öznelerin kurgulanması arzusunu içerisinde barındırır. Bu arzu kimi zaman devrimci potansiyel taşıyabileceği gibi statükonun korunması bağlamında da değerlendirilir.

Özneleştirme pratikleri ile anlatılan durum; özneyi pek çok açıdan evreni ve fenomenleri yorumlama bağlamında bir kurgulama çabasını gösterir. Özneleştirme teorisi sosyal fenomenlerin birincil alanının sosyal pratikler olduğu temel fikrinden ilerlemektedir. Bu pratikler tarihsel ve kültürel olarak gelişen, organize edilen, önceden belirlenmiş ve insan faaliyetlerinin sınırlarını aşan, çerçevelenmiş bir alanı işaret eder. İktidar ve bilgi sistemleri bağlamında karşımıza çıkan ve siyasal, dini, ahlaki vb. boyutlarda oluşan özneleştirmenin pratikte ortaya çıktığı alanlardan birisi de sanattır. Özneleştirme pratiklerinin yapısal olarak gerçekleştirilmesi maddi düzenlemelere bağlıdır. Bu durumda sanatın bir özneleştirme pratiği olarak ortaya çıkması onun fikirsel boyutunun maddeye dönüştürülmesi ile ilgilidir. Sanat eserleri bu madde oluş ile dilsel ve imgesel bir mücadele ve özneleştirme alanı oluşturmaktadır. Sanat eserleri insan olmayan özneleştirici yapılar olarak, yorum yapma ve bilgiyi kullanma yollarını kesin olarak belirlemek yerine estetik bir etki üretirler. Bu nedenle diğer özneleştirici pratikler gibi sanat karşısında da öznenin bir direniş gerçekleştirmek için özerkliği bulunur. Öznellik olarak tanımlanacak bu özerk alanda özne potansiyel olarak, özneleştirme pratiklerine direnerek kendisine sunulan kurguların dışına çıkabilir (Paras, 2016; Zizek, 2012, Brümmer, 2018).

Kültürel bellek unsurları da varoluşlarının bilgi ile bağlantısı nedeniyle bir tür özneleştirme pratiğidir. Öznelerin deneyimlemediği şeyler ile ilgili bilgi ve bu doğrultuda düşünce ve duygu aktarımı gerçekleştirildiği için hemen hemen tüm kültürel bellek pratiklerinin ayrıca estetik bir boyutu da vardır. Kültürel bellek alanında mücadele veren ve yukarıda iki temel kategoriye ayırdığımız sanat eserlerinin egemen ve alternatif söylemler çerçevesinde özneleştirici bir etki yaratma amaçları olduğunu ifade edebiliriz. Buna göre egemen söylemi tekrar eden sanat eserleri varolan özneleşmeyi pekiştirmek için estetik hazzı tasarlarken, alternatif söylemler ise sanatçıların kendi öznellikleri çerçevesinde ürettikleri bir direnişi göstermekte ve egemen söylemin ürettiği bellek ile mücadele veren bir tasarım gerçekleştirmektedir. Ancak bu durumda bile üretilen yeni öznellik bir tür özneleştirme arzusunu ontolojik olarak bize gösterir.

Sinema filmlerinde kültürel bellek bağlaminda gerçekleştirilen imgesel mücadeleyle sıkça karşılaşırız. Bu mücadelede hem egemen hem de alternatif söylemlerin öznelere, sunulan imgeler ve duygulamlarla özneleştirici etki yarattıkları belirtilmelidir. Sanatçının yaşadığı yeni öznelliklerin de, ürettiği eser ile alımlayıcı için özneleştirici bir pratiğe çevirdiği söylenebilir. Diğer bir ifade ile sanatçının yaşadığı öznellik bir estetik nesneye dönüştüğünde varoluş olarak özneleştirici bir unsura evrilir. Böylelikle sanatçı kendi öznelliklerini estetik bir objeye dönüştürmesiyle alımlayıcı üzerinde bir kuvvet uygular. Bu kuvvettin de duygulam bağlamında gerçekleştiğini ve bu nedenle kuvvetin kendisinin estetik haz olarak tanımlanabileceğini ifade edebiliriz.

Sanatın özneleştirici etkisini bir kuvvet olarak düşünmek ve alımlayıcıyı fenomenlerin yorumları bağlamında iki türlü etkilediğini söylemek gerekmektedir. İlk tür, öznelere fenomenlerin yorumlarını estetik haz bağlamında dayatmaktadır. Örneğin Hristiyan sanatında ki cehennem tasvirleri ürettikleri korku ile belli bir bakış açısını alımlayıcıya dayatmaktadır. İkinci türde ise sanat eserlerinin özneleştirici etkisi, fenomenler ile ilgili alternatif bakış açıları ile var olan kurguların sorgulanması ve tasarlanmış yeni öznellik alanlarının açılması noktasında itici bir kuvvet olarak belirmektedir.

İkinci türdeki özneleşme varoluş olarak öznenin üzerinde bir kuvvet uygulaması nedeniyle birinci türden farklı olsa bile sanatçının arzusu ile bağlantılıdır. Burada izleyici özne 
ile ilgili bir özgürlük sorunu ortaya çıkar. Estetik özne varolan tüm özneleştirici pratiklerin ve toplumsal kurguların dışında bir öznellikle karşı karşıya kalsa bile bu bir maruz kalma durumudur. Bu sebeple sanatçlların alternatif söylem ve öznellikleri de sanatla nesneleştiğinde bilgi düzeyinde verili oldukları için ontolojik olarak özneleştirici pratiklere dönüşür. Örneğin Antik Roma'da Hristiyan sanatının ilk örnekleri Pagan toplumu için yeni bir öznelliği sunmaktaydı. Fakat zaman içinde Roma toplumu içinde ortaya çıkan bu öznellik sanat eserleri vasıtasıyla güçlü bir özneleştirme pratiğine dönüşmüştür.

Alternatif yeni öznellikler olumlu veya olumsuz olarak yorumlanabilir. Bu sebeple üretilen her yeni öznelliği sanatın ilerici gücü olarak tanımlamak da sorunludur. Sonuç olarak sanatçıların ürettikleri öznellikler sanat eseri ve yarattığ 1 belirlenmiş estetik haz sayesinde bir özneleştirici yapıya sahiptir. Ancak bu özneleşme kimi zaman bir dayatma olarak karşımıza çıkarken kimi zamansa alımlayıcı öznenin mevcut belleği ile mücadeleye girerek farklı öznelliklerin mümkün olabileceğini gösterir. Burada yeni bir öznelliğin sanat eseri ile sunulmasının da özneleştirmeyle alakalı olduğu iddia edilmektedir. Alternatif ve eleştirel bakış açıları kendi bakış açılarını dayatmasalar bile özneleştirici yapıdadırlar. Buradaki özneleştirme durumu estetik özneye egemen söylemler karşısında bir direniş alanı açmakla ilgilidir. Böylelikle estetik özne için potansiyel olarak bir öznellik ve direniş alanının da sanatın uyguladığı kuvvet sayesinde söz konusu olabileceği ifade edilebilir. Düşüncenin gelişmesi, kalıpların kırılması, hakikat olarak kabul edilen şeylerin sorgulanması adına sanatçıların öznellikleri özneleştirici olsa bile son derece önemlidir.

\section{Film İncelemesi: "Brand New Testament"}

Estetik haz, bellek ve özneleştirme arasındaki bağlantı kapsamında incelenecek olan "Brand New Testament" isimli film Hiristiyan inancinda oluşturulan tanrı imgesi ile bir çeşit mücadeleye girmektedir. Bu mücadele sanat eserlerinin bellek üzerindeki etkisi ve öznelleştirici etkileri bağlamında da özel bir örnek olarak belirmektedir. Aşağıda incelenen filmin bir tasarım olarak estetik hazzı nasıl yarattığına dair ön ontolojik yapı üzerinde çalışılmıştır. Bu bağlamda karakter, eylem ve olay, mekân ve zaman bağlamında filmin ön ontolojik tabakasının sunduğu bilginin incelendiği ifade edilmelidir. İncelemeye geçmeden önce mitolojik söylemler çerçevesinde tanrı kavramının nasıl imgeleştirildiği, hem fiziki olarak hem de ruhani bir varlık olarak nasıl tasvir edildiğine değinilmesi gerekmektedir. Bu gereklilik filmin imgesel mücadelesi, bellek ve özneleştirici etkilerin belirlenebilmesi ile ilgilidir.

İlkel topluluklarda toplumu simgeleyen ve soyundan gelindiğine inanılan totemlerin zaman içinde toplumsal iş bölüşümü ve diğer parametrelerdeki değişimlere bağlı olarak tanrı kavramına evrildiği iddia edilmektedir. Tanrının uygar öncesinde ve özellikle ilk uygar topluluklarda imgeleştirildiği yani somutlaştırıldığı ve insanlaştırıldığ1 görülür. İlk uygar toplulukların ortaya çıktığı Mezopotamya'dan sonra, Antik Yunan ve Roma mitolojilerinde de insanlaştırılmış tanrılarla karşılaşılmaktadır. Bu uygarlıklarda tanrılar arasında aynı toplumdaki gibi bir iş bölüşümü bulunur ve tanrılardan bazıları diğerlerine göre daha güçlü olarak tanımlanmışlardır. Tanrıların hikâyelerini anlatan mitoloji ise pek çok düşünüre göre aristokratik düşüncenin üretimidir. (Şenel, 1996; Gombrich, 2007). Yunan ve Roma mitolojilerine bakıldığında ise tanrıların insani zaaflar sergiledikleri de görülür. Örneğin, Kronos yarattıklarını yok eden ve sonra tekrar yaratan acımasız bir tanrı, Zeus ise kız kardeşi Hera ile ensest ilişkiye giren, kaba güçle egemen olan bir varlık olarak tanımlanırken, diğer pek çok tanrının da kıskançlık, intikam, tecavüz, cinayet gibi olumsuz ve ahlaki anlamda sorunlu görülen şeyleri yaptıkları mitolojik hikâyelerde anlatılmaktadır (Buxton, 2016: 69-73).

Hıristiyan inancındaki tanrı imgesi ise biçem açısından dönemlerine göre değişim gösterse bile özellikle Rönesans sonrasında Antik Yunan etkisinde kalarak antik çağlardakine benzer bir şekilde üretilmiştir. Lakin imgeleştirilen tanrı biçimsel olarak Antik Yunan'daki tanrılara benzese bile asla mitolojideki gibi zaafları olan bir tanrı değildir. Hıristiyan inancında pek çok sanatçı, tanrı imgesini; yaşlı, otoriter, bilgili, güçlü, asil, yenilmez bir imparator ama 
aynı zamanda yarattıklarına karşı sevgi dolu bir varlık şeklinde tasarlar. Sanatçılar teolojik metinlerle uyumlu olarak kusursuz bir tanrı imgesi üretmişlerdir. Tanrı bu imgelerde bir baba figürüdür ve sanatçıların eserlerinde de isim olarak "baba" kavramı kullanılmaktadır. Da Vinci, Battista, Titian, Michalengelo, Rafello gibi sanatçıların eserlerinde kalıplaşmış bu imgeyi genel hatları ile görmek mümkündür. Elbette sanat eserlerindeki göstergelere teolojik söylem de anlam ve duygu olarak dâhil olmaktadır. Hristiyan teolojisinde çeşitli konulara göre tanrının eylemleri de sanatla gösterilmekte veya hikayeler şeklinde anlatılmaktadır. Çalışmanın sınırlılıkları çerçevesinde bunlardan tek tek söz edilmesi mümkün değildir.

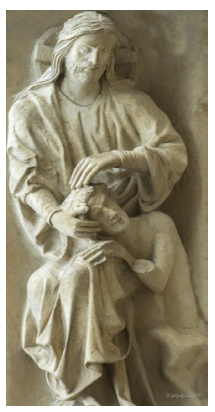

Görsel 1. "God loves Adam İnto Being" (anonim eser) 13. yüzyıl.

Görsel 1. ve pek çok örnekte görebileceğimiz şekliyle Hıristiyan sanatında tanrı yarattıklarına karşı sevgi dolu olarak tasvir edilmiştir. Görsel 1. deki heykelde Tanrı'nın Âdem'i sevdiği ve şefkat gösterdiği görülür. Viladeseu'ya (1999) göre tanrının insan şeklinde tasvirlerinin pragmatik bir amacı bulunmaktadır. Bu amaç çerçevesinde tanrı, insanları kendisi gibi yaratır yani kendi özellikleri yaratılanlarda da vardır. Bu heykelden çıarılacak anlam bu doğrultuda sevginin tanrısal bir duygu olduğu yönündedir. Âdem'i seven tanrı, sevginin varoluşunun ana koşullarını yaratır. Bu sebeple sevgi tanrısal bir durum olarak karşımıza çıkar.

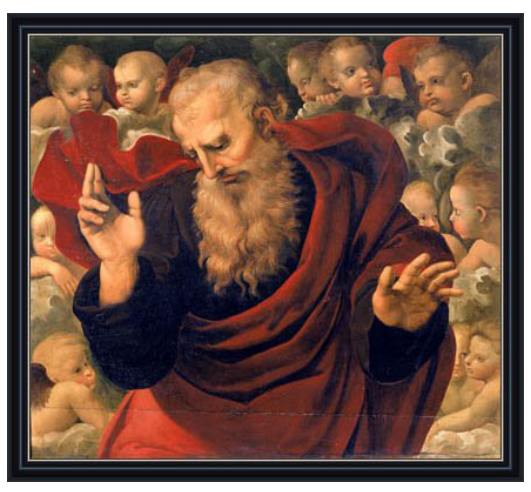

Görsel 2. Raphael'in "God the Father Blessing" isimli ve 1508 tarihli eseri.

Yukarıda Görsel 2. ise resim sanatındaki örnek bir kalıbı göstermektedir. Bu kalıp çerçevesinde Rönesans sonrası tanrı imgesinin "God the Father Blessing" eserindeki gibi yaratıcı, asil, yenilmez bir güç olarak yaratıldığı gözlemlenir. Ancak göstergesel bir okuma yapıldığında tanrı tasvirinin olumsuz hiçbir eylemle birleştirilmediği aksine sevgi dolu ve bilge bir insan şeklinde üretildiği görülür. Bu tasvirin dışında yapılan araştırmalar sonucu tanrının Hristiyan sanatında asla yarattıklarına eziyet ederken tasvir edilmediği söylenebilir.

Messadie, tanrının yarattıklarını sınamak üzere şeytana kutsal bir görev verdiğini yazar. Hıristiyan teolojisinde başlangıçta "ahlaksız ruh" olarak tanımlanan şeytanın sonradan tanrının bir hizmetkârı olarak, insanları sınama görevini üstlendiği görülür (1999, 421-435). Bu söylem hiçbir kötülüğün tanrıdan veya hizmetkârı şeytandan gelmediği ve insanların bir sınavda oldukları için kötülüğü ve acıyı kendilerinin yarattığı anlamına gelir. Bu bağlamda Hristiyan teolojisinde de sanatsal tasvirlerde gösterildiği gibi kötülük asla tanrıdan değildir 
ve insana has bir durumdur.

"Brand New Testament" isimli film ise, kültürel bellekte özneleştirici bir imge olarak varolan Hıristiyan inancındaki tanrı imgesini ters yüz etmektedir. Bu imge küreselleşme, medya ve kültürel emperyalizmin çeşitli unsurları sayesinde dünyada başka inançlara da nüfuz etmiş bir imgedir. Filmin bu imgenin karşısına bir alternatif bir kültürel bellek üretmeye çalıştı̆̆ 1 görülmektedir. Filmin egemen tanrı imgesini ters yüz edişi, filmde tanrı karakteri ile birlikte diğer tüm karakterler ve eylemler ayrıca mekân ve zaman tasarımlarının bir bütün olarak var edilmesiyle bağlantılıdır. Yönetmenin yarattığı tanrı imgesi ile ilgili yeni bir düşünceyi, duygulama yani estetik hazza çevirmek isteyen filmin karakterleri ise şu şekilde tasarlanmıştır:

Tanrı: Yönetmenin anlatısındaki en önemli tasarımlardan birisi olarak tanrı, hem görsel hem de dilsel göstergeler ile ruh sağlığı yerinde olmayan bir karakter olarak yaratılmıştır. Bu figür kültürel bellekte aktarılan tanrıya görsel olarak benzemediği gibi onun zıddı özellikleri taşıyan, özellikle Hollywood filmlerinde karşılaştı̆̆ımız alt sosyo-ekonomik düzeydeki bir taşralı baba tiplemesidir. Görüntü olarak çirkin denebilecek, evde aile halkının varoluşunu olumsuz etkileyen, baskıc1, nefret dolu bir karakter olarak Brand New Testament isimli filmin tanrı karakteri yarattıklarına karşı da oldukça acımasızdır. Diğer taraftan insanların varoluşları ile ilgili sorunların yaratıcısı olarak teolojideki şeytan figürünün filmde olmaması bir sinematik göstergenin var olmadan da anlama etkisini bize göstermektedir. Şeytanın filmde olmaması ve olan tüm insani olayları tanrının kuralları çerçevesinde insanların yaşamaları filmin tanrısının her şeyi kontrol ederek kötülüklerin de asıl sorumlusu olarak belirmesine neden olur.

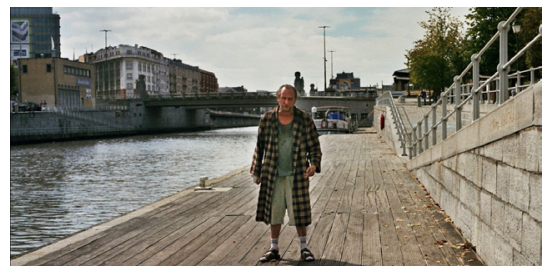

Görsel 3. Brand New Testament'in tanrı karakteri.

Kültürel anlamlar çerçevesinde günümüz için çirkin olarak tanımlanabilecek bir bedene sahip olan tanrı karakterinin kıyafet seçimleri de alt sosyo-ekonomik düzeye aittir. Kiyafetlerin daha önceden medya ve sinemada yaratılan olumsuz imgelerle iş birliği yaptığı söylenebilir. Görsel 3. İle gösterilen bu beden ayrıca yakın çekimlerle sunulan duygulanım imgeleriyle de negatif duygulamlar üretmektedir.

Elindeki gücü olumsuz kullanan Brand New Testament'ın tanrısı bir yandan da mitolojideki Kronos'a ve Zeus'a gönderme yapmaktadır. Kronos sürekli olarak var ettiklerini yok etmesi ile bilinirken, Zeus ise acımasızlığı ile tanınan bir tanrıdır. Ayrıca kızını banyoda dikizlediği sahne Zeus'un cinsel yaşamına yapılan önemli bir gönderme olarak yorumlanabilir. Diğer taraftan bu sahne, aile için cinsel ilişki yani ensest ile ilgili olumsuz düşünceleri tanrı figürü ile ön ontolojik tabakada birleştirmektedir. Filmin içinde gerek bedensel çirkinliği gerekse olumsuz eylemleri ile karşılaştı̆̆ımız İsa'nın babası ve Hıristiyan inancındaki Tanrının, filmdeki görüntüsü ile imgesel bir mücadeleye sürüklendiği ifade edilebilir. Bu sebeple yönetmenin Hıristiyan inancındaki tanrı imgesi ve buna eşlik eden düşünceleri, antik tanrılarla ve günümüz toplumlarındaki sorunlu insan karakterinin imgeleri ile yer değiştirmeyi amaçladığını ve yeni bir imge ile başka bir tanrı düşüncesi ve buna bağlı negatif duygulamlar oluşturmak istediğini söyleyebiliriz.

Ea: Tanrının bilinmeyen kızıdır. Filmde Tanrıya başkaldıran ve yeni öznellikleri üreten karakter Ea'dır. Ea insanların varoluş bunalımlarını görerek babasına sinirlenir ve dünyaya gitmeye karar verir. Kendisine havariler bulan Ea sonuç olarak babası ile girdiği mücadeleyi kazarak insanlara yeni bir varoluş olanağı sağlayacaktır. Ea karakterinin tasarımı mitolojideki kimi karakterle benzerlik gösterir. Ateşi insanlığa armağan eden Prometeus gibi Ea da insanlığa yardım etmek için kendi varlığını tehlikeye atar. Ayrıca Ea insanlara rüyalar 
gösterebilmektedir ve bu özelliği ile mitolojideki Morpheus' $\mathrm{a}^{12}$ benzemektedir. Bu benzerlikler ön ontolojik yapıda doğrudan verilmemiştir. Ancak filmin olayları ile kültürel belleğin bilgi hazinesinde yer alan metinler ve göstergeler arasındaki iş birliği filmde aşikârdır. Bu sebeple yönetmenin bu bağlamda antik mitlerle metinler arası bir ilişki kurduğu iddia edilebilir.

Bir tasarım olarak Ea karakteri tanrı karakterinin antagonistidir. Tanrı imgesinin değiştirilip yeni ve alternatif bir bellek üretmek adına Ea karakteri yaratılmıştır. Bu karakter yönetmenin öznelliklerini gösterdiği karakterlerden birisidir. Tanrıya başkaldırış ve bu eylemin olumlu duygulamlar üretmesi adına üretilen Ea karakteri ayrıca bir kadın Mesih figürüdür.

Jc (İsa): İsa'nın filmde babasına ilk başkaldırıyı gerçekleştirdiği ve sonrasında ise kendisini öldürttüğüne yönelik bir söylem bulunur. İsa filmde bir ikon olarak varlığını devam ettirmektedir. Başkaldırıda Ea'ya yol gösteren İsa'dır. İsa karakterinin filmde yer alması ayrıca tanrının Hristiyan inancının tanrısı olduğu fikrini yaratmak içindir.

Anne Tanrıça: Erkek egemen toplumda bastırılmış kadınları temsilen tasarlanan anne tanrıça, tanrının yaptıkları karşısında tepkisizdir. Bu durum mitolojilerde tanrıça figürlerinin zamanla tanrı figürlerine yerini terk etmesini çağrıştırır. Filmde tanrı onu üretici faaliyetin dışına atmıştır. Bu bağlamda anne tanrıça figürünün filmin sonundaki yaratıcı eylemi toplumsal üretimin dışına atılan ve ev işlerine mahkûm edilen kadınların aslında hem toplumsal hem de bireysel varoluş alanlarında son derece yaratıcı olabileceğini göstermek üzere tasarlanmıştır. Diğer taraftan erkek egemen ve acımasız dünya tasarımı ile ilgili olarak filmin anne tanrıçayı bir çözüm unsuru olarak sunduğu söylenebilir.

Filmde havariler olarak sunulan Aurelle, Jean Claude, Francois, Martin ve Willy karakterleri ile insan varoluşunun bazı bunalımlarına değinilmektedir. Tüm bu karakterlerin ortak özellikleri yalnız olmalarıdır. Fakat Ea sayesinde bu karakterler hem varoluş sancılarından hem de yalnızlıklarından kurtulurlar. Bu karakterler inanç ve tanrısal varlıklar arasındaki bağlantı noktasında, insan inancı olmaksızın tanrısal olanın anlamsız olacağ1 düşüncesi ekseninde var edilen karakterlerdir. Dolayısıyla Ea' nın direnişinin başarısı teolojide de olduğu gibi bu inanç faktörüne dayanır ve kendisine inananların olması başarının anahtarıdır. Bu karakterlerin dışında 62 yıl yaşayacağını bildiği için ölümcül eylemler gerçekleştiren Kevin karakteri, Yeni Ahit'i yazıya döken Viktor karakteri ve Tanrıya şiddet uygulayan Rahip karakterleri de filmin tasarımına dolaylı olarak etki eden karakterlerdir. Rahip karakteri filmdeki küçük rolüne rağmen son derece etkili duygulamlar üretir. Bu duygulamlar karakterin tanrıya verdiği tepki ile ilgilidir ve gülme boyutunda tasarlanmıştır.

Filmdeki karakter eylemleri ve olaylar değerlendirildiğinde genel görüntü, tanrı karakterinin eylemlerinin bu karakter ile ilgili negatif düşüncelere neden olacağı yönündedir. Filmin olay örgüsü de bu sebeple tanrı karakterinin negatif eylemlerinin ortadan kaldırılmasına yönelik diğer karakter eylemleri ile oluşturulmuştur. Tüm olaylar izleyeni filmdeki acımasız tanrının devre dışı bırakılmasına hazırlamak için tasarlanmıştır. Özellikle filmde havarilerin yaşadıkları varoluş sorunları tanrısal tasarımın bir parçası olarak gösterilmiş ve tanrı devre dışı bırakıldığında bu sorunların ortadan kaldırılacağına dair bir söylem üretilmiştir.

Brand New Testament'da gerçekleştirilen mekân tasarımları filmin yaratmak istediği kasıtlı düşünce ve duygulamların önemli bir parçasıdır. Filmin tanrı tasarımı bağlamında oluşturulan tanrısal mekânlar, sanat tarihi ve teolojik söylemin anlatımlarından bir hayli farklıdır. Tanrının evi bir apartman dairesi, çalışma odası ise modern bir arşiv bürosu şeklinde tasarlanmıştır. Tanrının evi sosyo-ekonomik olarak alt sınıfa ait eşyalarla dekore edilmiştir. $\mathrm{Bu}$ durum tanrının bedensel görüntüsüyle ilgili gerçekleştirilen tasarımı güçlendirir. Tanrı ayrıca gücünü bir bilgisayardan almaktadır. Tanrının mekânsal yer değişiklikleri de fizik

12 Morphe Latince biçim demektir. Uyku tanrısı Hypnos'un çocuklarından birisi olan Morpheus insanlara uykularından çeşitli biçimler ve simgeler sunmaktadır (Erzat, 1997: 208) 
kurallarından bağımsız değildir. Dünyaya inmek için çamaşır makinesini kullanan tanrı, bu mekan tasarımları ile insanlaştırılmanın ötesinde pek çok zaaf ile var edilmiş bir varlıktır.

Filmin zamanı Aion ${ }^{13}$ şeklinde tasarlanmıştır. Deleuze (akt. Zizek,2015: 63) bu zamansal tasarımda Aion' un karşısına Kronos'u koymaktadır. Kronos'ta zamanı sadece şimdiki zaman oluştururken, Aion'da geçmiş ve gelecek, şimdiki zamana sürekli müdahale etmektedir ve bu nedenle üç boyutludur. Kronos bir döngü yaratır ve sürekli tekrar eden bu döngüde önce düzen kaosu, sonrasında ise kaos düzeni yeniden yaratır. Diğer bir ifade ile önce varolan koşullar bozulur ve sonra tamir edilir. Aion ise sınırsız bir değişim potansiyelini göstermektedir bu sebeple de sürekli kaotiktir. Aion zamanın saf ve boş hali, Kronos ise zamanın belirlenmiş biçimlendirilmiş halidir.

Brand New Testament'da özellikle dilsel göstergelerin kullanılarak zamanda geri gidişlerin gerçekleştirildiği ve zamansal değişimin filmde odakta olduğu görülmektedir. Diyaloglarla filmin anlatısına ve zamanına yapılan müdahale Aion için temel unsurlardan birisidir. Filmin zamansal olarak Aion şeklinde tasarlandığının düşünülmesinin diğer bir nedeni ise filmde tanrısal koşulların filmin başlangıcında farklı, sonunda farklı olarak gösterilmesidir. Sinematik bir zaman olarak Aion'nun, Brand New Testament'da tasarlanması tesadüf değildir. Film yönetmenin sanatsal öznelliklerini ortaya koymaktadır. Bu durum değişimi bize gösterir ve bu değişimin zamansal açıdan çizgisel devam ettirilmesi, başa dönüşün olmaması ve değişimin sonlandırılmaması da Aion'u yaratır. Zamanın filmde Aion olarak yaratımı Hıristiyan teolojisindeki değişmeyen belirlenmiş ve sonlu zaman fikrinin karşısındadır. Bu durum filmin sonunda erkek tanrının devre dışı bırakılması ile yaratılır. Diğer taraftan filmde tanrının kendisi yarattığı dünyada yukarıda da belirtildiği gibi Antik Yunan'daki Kronos benzeri bir zaman algısı yaratmıştır. Buna göre insanlar şimdiki zamanda biçimlendirilmiş ve değişime kapalı bir zamanı yaşarlar. Bu zaman algısı ile insanların ölüm zamanlarını bilinmemesi arasında güçlü bir ilişki vardır. Ea'nın insanlara ölüm zamanını bildirmesi filmde yaratılan dünyanın kendisinin de zamanı değişim bağlamında Aion olarak yaşamasına neden olur. Bundan sonra öznelerin değişim süreci başlar ve belirlenmiş veya biçimlendirilmiş zaman, yerini belli olmayan, değişime açık bir zamana bırakır.

Ön ontolojik tabakanın sunduğu bilgi ışığında karakter, eylem, mekân ve zaman ile ilgili yaratılan tasarımın öncelikle düşünsel olarak Hıristiyan inancı ve tanrı düşüncesine karşı geliştirilmiş bir tür eleştiri olduğu ifade edilebilir. Fantastik bir biçimde gerçekleştirilen bu eleştiride filmin yarattığ 1 tanrı ile ilgili izleyende negatif düşünceler oluşturulmak istenmiştir. $\mathrm{Bu}$ negatif düşünceler ise filmde tanrı figürünün hem görüntüsü hem de eylemleri ile ilgili olarak öfke, tiksinme, nefret gibi bazı olumsuz duygulamları yaratmaktadır. Örneğin Tanrının Ea ve anne tanrıçaya şiddet uyguladığı sahneler izleyenin bir film karakteri olarak tanrıya öfkelenmeleri için tasarlanmıştır. Tanrının çirkin görüntüsü ve olumsuz eylemlerinin eşleştirilmesi bu duygulamları güçlendirmektedir. Nitekim bir kötü karakter olarak tasarlanan tanrının sürgünü ise filmde sevinç türevi duygulamları yaratacaktır.

Filmde sevinç türevi diğer duyguların tasarımı aynı zamanda filmin estetik kategorisi hakkında bize bilgi verir. Tanrı karakterinin başarısızlıkları ve diğer pek çok unsur Brand New Testament'da komedi (gülme) kategorisinde tasarlanmış, izleyenin gülmesi için diyalog ve görseller üretilmiştir. Bu bağlamda estetik öznenin yaşaması için tasarlanan keder türevi duygulamların, güldürü unsuru tarafından aşıldığı ve filmin imgesel mücadelesinin en önemli silahının gülme olduğu belirtilmelidir. Gülüncün doğal ortamı kayıtsızlıktır ve özellikle acıma, korku gibi duygular gülmenin düşmanıdır diyen Bergson (2014) gülmenin toplumsal bir şey olduğunu ve özneler arasındaki bir suç ortaklığını gösterdiğini vurgulamaktadır. Gülme insanın anlam dünyasındaki katılıklara verilen bir tür cezadır. Gülmenin toplumsal yönü bağlamında Bergson'a göre bir şeye gülen kişinin diğerleri ile uyum sağladığı anlamı da ortaya çıkmaktadır.

\footnotetext{
${ }^{13}$ Aion İran kökenli bir kelimedir. Antik Yunanda sonsuzluğun ve sonsuz yaratıcılığın tanrısıdır.
} 
Brand New Testament filminin tanrısı, varoluşla ilgili katı olan her şeyin sorumlusu olarak filmde komedi unsurunun ana karakteridir. Bu karakter aslında yaptığı kötülüklerden ziyade

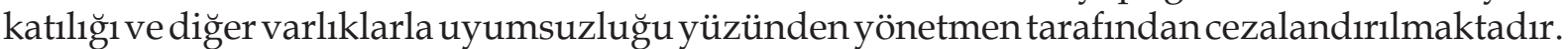
Film vasıtasıyla bu karaktere gülen estetik özneler ise filmde yaratılan tanrı düşüncesi ile ilgili suç ortaklığı yapmaya başlarlar. Komedinin diğer tüm estetik kategorilerden farklı olarak yıkıcı etkisi filmde bu noktada ortaya çıkar. Komedi unsurları genel geçer olan ve evrensel olduğu iddia edilen her şeyin karşısına yıkıcı bir güç olarak çıkmaktadır. Gülme ile estetik hazzın doruğuna ulaşan estetik özne için filmde, tanrı ile ilgili üretilen düşünceler meşrulaştırılmak istenmiştir. Estetik özne adına yaratılan bu deneyim estetik hazzın oluşması ile estetik öznenin varoluşunun bir parçasına dönüşmektedir. Bu durumda dışsal bir bellek olan filmin estetik haz sonrasında içsel bir belleğe dönüştüğü de iddia edilebilir.

Kültürel bellek alanında estetik özneye kuvvet uygulayan Brand New Testament, öznelerin belleklerinde bulunan imgelerle girdiği mücadelede özneleştirici etkisini, yaratmaya çalıştığı duygulamlar ile sağlar. Estetik özneler filmde tanrı ve varoluş ile ilgili üretilen duygulamları, tasarlandıkları hali ile deneyimliyorlarsa filmin özneleştirici etkisi başlamaktadır. Ancak duygulamların ortaya çıkması öncelikle bir düşünceye ve doğrudan bilgiye dayanmaktadır. Duygulamların tasarlandıkları hali ile hissedilmesi filmin sunduğu bilgi ve düşüncelerinin doğruluklarının kabulü anlamına da gelmektedir. Böylelikle bir fenomen olarak tanrı ile ilgili üretilen kurgular ve duygulamlar tanrının sabitlenmiş imgesini sorgulamaya açar. Yönetmenin, tanrı ile ilgili ürettiği öznelliklerini sinema vasıtasıyla nesneleştirmesi sonrasında sinematik imgelerin ürettiği duygulamlar, sanatçının öznelliklerini özneleştirici bir etkiye çevirmektedir. Ancak Brand New Testament'ın özneleştirici etkisi bir itici kuvvet olarak alternatif bakış açısıyla varolan tanrı imgesinin sorgulanmasını sağlamaktadır. Bu sorgulama nedeniyle filmin özneleştirici etkisinin estetik öznelere bir bakış açısı sunmakla birlikte özerk bir alan da bıraktığı görülmektedir. Komedi faktörünün devreye girişi ve filmin öznelere yeni bir teolojik bakış açısını dayatmak için değil var olan bakış açılarının sorunlarını göstermek üzere tasarlanmış olması bu özerk alanı yaratır. Böylelikle özne üzerinde filmin uyguladığı kuvvet varolan inanç ve düşünceleri eleştiriye açmaktadır. Bu sebeple sanatçının yarattığ tasarımın var olan kültürel belleğin yerine geçmesi ve yeni tanrı imgesinin sabitlenmesi gibi bir amacının olmadığı da vurgulanmalıdır.

\section{Sonuç}

Sinema filmleri, tasarlanmış pek çok sinematik imgeyi estetik öznelere sunarak estetik haz üretmektedir. Bu imgelerden bir kısmı sadece görüntü boyutunda, bir kısmı ise ses unsurları ile birlikte izleyenin karşısına çıkar. Tüm bu biçem unsurları bir ön ontolojik tabakayı göstermektedir ve bu tabaka; yaratılmış karakterler, eylemler (olaylar), mekân ve zaman tasarımlarının nesneleşmiş halleri olarak eserin verili içeriğini izleyene sunar. $\mathrm{Bu}$ durum bir çeşit organizasyon olarak okunursa, organize edilen fikirsel ve maddesel unsurlar ile izleyende, belirlenmiş duygular oluşturulmak istenmektedir. Bu duyguların yaratımı öncelikle kasıtlı düşüncelerin alımlayıcının zihinde oluşması ön koşuluna bağlıdır. Düşüncenin varoluşu ise bilgi ile doğrudan ilgilidir. Böylelikle tasarlanmış bir duygunun sanat eserleri vasitasıly estetik haz yaratması, sanat eserinin amacı bilgi aktarmak olmasa bile, bir eserlerin bilgi nesnesi olarak kabul edilmesi ön koşulunu işaret eder.

Plastik sanatlardaki diğer türler gibi sinema da, tasarlanmış duyguları estetik öznede oluşturmaktadır. Bu duyguları gündelik hayattaki duygulardan ayırmak adına duygulam kavramının kullanıldığı görülür. Sinemada estetik haz kavramı ise bir filmin tasarlanmış tüm duygulamlarını kapsamaktadır. Sinema filmleri ile estetik haz yaşayan estetik özneler salt bir hazlanmanın ötesinde potansiyel bir etki tarafından kuşatılmışlardır. Estetik hazza ulaşan özneler için filmlerdeki düşünce ve duygulamlar, dışsal bir bellek ve sanal bir deneyim olarak öznelerin içsel belleğine nüfuz eder diyebilmekteyiz. Estetik hazzın yani duygulamların yaşanması, filmin tasarımının ya da yönetmenin kasıtlı düşüncelerinin özneye aktarıldığını bize gösterir. Bilginin alanında gerçekleşen bu özel varoluş için ayrıca, "duygu boyutunda 
etkisini gösteren estetik nesneler, insan hayatının önemli birer deneyim unsuru olarak özneleştirici bir etkiye de potansiyel olarak sahiptir" denebilir.

Çalışmada incelenen Brand New Testament' da olaylar ve eylemler, karakter, zaman ve mekân tasarımları ile üretilen kasıtlı duygulamlar izleyende eleştirel bir bakış açısı ile Hıristiyan inancındaki tanrı ve varoluş düşüncesi hakkında yeni ve alternatif bir bellek yaratma amacındadır. Filmin yarattığ 1 yeni tanrı karakterinin sunduğu alternatif bellek ile Hıristiyan teolojisinde ve sanatında, göklerdeki ulaşılmaz, sevgi dolu ve asil gücün ilahi projesi ile ilgili yüzyıllardır varolan ve korunmaya çalışılan egemen kültürel bellek, imgesel düzeyde mücadeleye girmektedir. Özellikle Ea karakteri, tanrı karakterinin karşıtı olarak insan varoluşu için babasına karşı direnişi başlatır. Böylelikle Hıristiyan teolojisine karşı bir tür eleştiri geliştiren Brand New Testament'da, tarihi süreçte insanın başına gelenlerle ve yaşanan varoluş sorunları ile Hristiyan teolojisinin anlattığı veya sanatla gösterdiği tanrı arasında bir çelişki olduğu ortaya konulmaktadır. Anlattığı konu ve gösterdiği çelişki çerçevesinde estetik öznelere yeni bir deneyim sunan filmin, kültürel bellekle sunulan ve sabitleşmiş imgeler üzerinde yıkıcı bir etki yaratma potansiyeli söz konusudur. Ancak filmin ürettiği gerçeklik mücadele ettiği gerçekliğin yerine teolojik açıdan geçme potansiyeli ve amacı taşımamaktadır.

Estetik öznelerin belleklerinde teolojik açıdan yeni bir tanrı imgesi yaratmaktan ziyade varolanı sorgulatmak için tasarlanan bir kültürel bellek unsuru olarak Brand New Testament'da, estetik hazzın komedi temelli var edildiğini ve gülmenin yıkıcı etkisinin kullanıldığı belirtilmelidir. Güldürü unsuru filmdeki tanrı karakterinin katılıkları, zaafları ve güçsüzlükleri üzerinden üretilmiştir. Hıristiyan sanatında ve teolojisinde son derece güçlü bir karakter olarak karşımıza çıkan tanrı imgesi filmdeki yeni tasarımı ile farklı bir gerçekliği sunar. Filmin ürettiği duygulamlar estetik öznede tasarlandığ 1 şekilde oluştuğu anda filmin belleğe müdahalesi ve özneleştirici etkisi de başlamaktadır. Ayrıca filmin ürettiği estetik haz sadece gülme üzerinden ilerlememekte ve bazı sahnelerde tasarlanmış nefret, öfke ve tiksinme gibi duygulamlar da bulunmaktadır.

Filmin özneleştirici etkisi ile uygulanan kuvvet arasında önemli bir bağlantı söz konusudur. Gülme ile yaşanan estetik hazzın yarattığ1 özneleştirme daha çok varolan özneleştirme pratiklerine güçlü bir eleştiri ve bir saldırı şeklinde okunmalıdır. Bu durumda filmin ürettiği belleğin alternatif bir bellek olarak kendini yeni bir teolojik hakikat şeklinde dayattığını söylemek mümkün değildir. Pek çok sanat eserinin ürettikleri gerçeklikleri hakikat olarak sunma iddiası bulunurken, Brand New Testament fantastik özellikleri ve estetik kategori olarak komedi alanında yer alması nedeniyle bu hakikilik iddiasından uzaktır. Bu noktada filmin varoluşu, varolan kültürel belleğin sorunlarının ortaya konulması ile ilgilidir. Ayrıca filmdeki komedi unsurları, genel olarak estetik öznenin kendisinin bir toplumsal özne olarak nasıl kurgulandığının anlamasını sağlayacak bir kuvvet uygular. Bu kuvvet varolan kurguların hakikat iddiasını sorgulamaya açar. Filmin buradaki özneleştirici etkisi estetik özneyi eleştirel bir perspektiften Hıristiyanlıktaki Tanrı ve varoluşu görüp değerlendirme bağlamında ortaya çıar. Elbette burada izleyene dayatılan bir bakış açısı söz konusudur. Ancak genel olarak filmin özneleştirici etkisinin eleştirel unsurlardan dolayı estetik özneye özerk bir alan bıraktığı da ifade edilmelidir. Başka bir ifade ile filmde sunulan tanrı imgesi yeni bir sanatsal öznelliktir fakat estetik bir varlık olarak sunulduğunda ontoloji açıdan bir özneleştirme unsuru olarak izleyene kuvvet uygular. Tanrı ile ilgili üretilmiş tüm imgeler estetik öznelerden önce tasarlanmış birer estetik düzenektir. Filmdeki tanrı tasarımı egemen söylemin dışında yeni bir öznellik olsa bile izleyenin dışındaki bir bilgi ve iktidar alanında yer alır ve bu sebeple

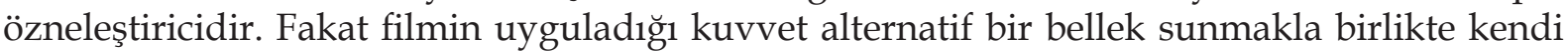
kurgusunu dayatma durumundan uzaktır ve öznelere konu ile ilgili özneleştirici etkisi olan kültürel belleğin dışına çıkarak bir tür direniş gerçekleştirme olanağı tanımaktadır. Bu durumda yönetmenin kendi öznelliği, film ile her ontolojik bağlamda özneleştirici bir pratiğe teorikte dönüşse bile kimi estetik stratejilerle estetik özneye özerk bir alan yaratılmaktadır. $\mathrm{Bu}$ alanda estetik öznelerin üretecekleri öznellikleri tespit etmek bu çalışmanın sınırlılıklarını 
aştığı gibi imgenin aşkın halleri ile bağlantılıdır.

\section{Kaynakça}

Assman, J. (2001). Kültürel Bellek, çev. Ayşe Tekin, İstanbul: Ayrıntı Yayınları.

BERGSON, H. (2014). Gülme: Gülüncün Anlamı Üzerine Deneme, çev. Devrim Çetinkasap. İstanbul: Türkiye İş Bankası Kültür Yay.

Bonnard, A. (2014). Antik Yunan Uygarlığı-3. Ankara: Evrensel Basım Yayın.

Bozkurt, N. (2013). Sanat ve Estetik Kuramları.İstanbul: Sentez Yayıncılık.

Brümmer, K. (2018). Subjectivation By Video:Ethnographic Explorations On Practices Of Video Analysis In High-Performance Youth Football. German Journal Of Exercise And Sport Research, 48(3), 358-365.

Buxton, R. (2016). Yunan Mitolojisi, çev. Ahmet Fethi Yıldırım. İstanbul: Alfa Basım Yayım.

Cicovacki, P. (2015). The Analysis Of Wonder: An Introduction To The Philosophy Of Nicolai Hartmann. USA: Bloomsbury Publishing.

Cooper, D. E., Margolis, J., \& Sartwell, C. (1992). A Companion To Aesthetics. Oxford, UK: Blackwell.

Erzat, A. (1997). Mitoloji Sözlüğü. İstanbul: Remzi Kitapevi.

Deleuze, G. ve Guattari F. (2001) Felsefe Nedir?, çev. Turhan Ilgaz, İstanbul: Yapı Kredi Yayınları.

Fraser, I. (2008). Hegel ve Marks İhtiyaç Kavramı, çev. Beyza Sumer Aydaş, Ankara: Dost Kitabevi.

Gadamer, H. G. (2009). Hakikat ve Yöntem. çev. Hüsamettin Arslan ve İsmail Yavuzcan. İstanbul: Paradigma Yayınları.

Gombrich, E. H. (2007). Sanatın öyküsü, çev. Erol Erduran ve Ömer Erduran. İstanbul: Remzi Kitabevi.

Hartmann, N. (2010). Ontolojinin Işı̆̆ında Bilgi. İstanbul: Türkiye Felsefe Kurumu.

Hartmann, N. (2014). Aesthetics. Berlin: Walter de Gruyter GmbH \& Co KG.

Kagan, M. (1993). Estetik ve Sanat Dersleri, çev. Aziz Çalışlar. Ankara: İmge Yayınevi

Messadie, G. (1998). Şeytanın Genel Tarihi, çev. Işık Ergüden. İstanbul: Kabalcı Yayınevi.

Neu, J. (2000). A Tear İs An İntellectual Thing: The Meanings Of Emotion. UK: Oxford University Press.

Nietzsche, F. (2005). Tragedyanın Doğuşu, çev. Mustafa Tüzel. İstanbul:İthaki Yayınları.

Nita, B. F. (2014). Intentional Image And Transcendental Image In The Work Of Art: An Ontological Analysis. Akademeia, 4(1), ea0124.

Paras, E. (2016). Foucault: Öznenin Yitiminden Yeniden Doğuşuna, çev. Yunus Çetin. İstanbul: Kollektif Kitap.

Schudson, M. (2007). Kolektif Bellekte Çarpitma Dinamikleri. Cogito, 50, 179-199.

Solomon, R. C. (2004). Thinking About Feeling: Contemporary Philosophers on Emotions, Oxford: Oxford University Press

Spinoza, B. (2011). Etika, çev. Hilmi Ziya Ülken, Ankara: Dost Kitabevi. 
Şenel, A. (1996). Siyasal Düşünceler Tarihi. Ankara: Bilim ve Sanat Yayınları.

Tunalı, İ. (1973). B. Croce Estetik'ine Giriş. İstanbul: İstanbul Üniversitesi Edebiyat Fakültesi Yayınlar1

Tunalı, İ. (1996). Estetik. İstanbul: Remzi Kitabevi.

Timuçin, A. (2004). Felsefe Sözlüğü, İstanbul: Bulut Yayınları.

Viladesau, R. (1999). Theological Aesthetics: God In Imagination, Beauty, And Art. New York: Oxford University Press.

Zizek, S. (2015). Hiçten Az: Hegel ve Diyalektik Materyalizmin Gölgesi. İstanbul: Encore Yayınları. 